relation to development are discussed at length. That embryological differentiation is not a sorting out of genes is clear, but present evidence is insufficient for deciding between various possible views of the ways in which the genes control development. (1) All genes may be active all the time, producing different results by their action on different parts of the egg cytoplasm. (2) Different batteries of genes may come into action at different stages of development, or at different rates, as Goldschmidt has postulated for sex-genes. (3) Possibly the kind of activity of the genes changes in response to the kind of protoplasm in which they lie. Finally, the relation of genetics to medicine is touched upon, and the importance of the developments in human genetics is recognised in relation to the inheritance of human defects, mental and physical. It is predicted that hundreds of cases of genetic linkage in man will be discovered.

\section{Teaching the Value of Forests}

ONE of the troubles in connexion with forestry and afforestation in Great Britain is the loss by the population of what, for want of a better term, has been termed the 'forestry sense'. Out in the Empire the difficulties of the forest officer arise from other causes. In each case it is sought by propaganda and education to teach the people the true value of the forest and its position in the economic structure of nations and the lives of the population. The Forestry Department in Trinidad is issuing a series of Forestry pamphlets "for teachers". No. 3 of the issue (Trinidad : Government Printer, Port-of-Spain, 1934) is entitled "Timber: Its Structure, Properties, Seasoning and Preservation" by Mr. R. L. Brooks, the conservator of forests. The pamphlet is illustrated by simple diagrams.

OF a somewhat different type, but having the same object in view, is the handbook to a temporary exhibition (May-September) based on the tree collections in the Department of Botany in the National Museum of Wales. This small brochure is entitled "Some Aspects of Forestry in Wales" (Cardiff 1935). The handbook has been prepared by Mr. H. A. Hydes. In a preface, Dr. Cyril Fox, the director of the Museum, writes: "The Forestry Act of 1919 authorised the formation of large State Forests and has thus broadened immeasurably the basis of forest ownership. Every man is now an owner of plantations, and should have some idea of how and why they are created and maintained. Such problems as the relative values of broad-leaved trees and coniferous trees as forest crops, and the scenic effect of planting introduced species along with native trees, which are now freely discussed in the Press, can only be understood in the light of at least a minimum of knowledge of the species concerned and of their relation to forestry in general." The exhibits are set out under the headings : Welsh forest botany, forest operations, forest pathology, wood anatomy and utilisation of forest produce. Among interesting exhibits are those relating to the beautiful woods of the Wye Valley, afforestation of sand dunes in South Wales, and the well-known plantations at
Lake Vyrnwy, the chief reservoir for supplying water to the city of Liverpool. Those plantations now amount to 4,500 acres out of the total area of 5,000 acres which it is proposed to plant.

\section{Literature of the Occult}

Although the consideration of magic is a necessary prelude to the study of primitive religion, and, as such, lays claim to no inconsiderable share in the literature of anthropological science, it forms relatively only a small proportion of the vast accumulation of printed matter which has grown up in ralation to magic in the larger sense, more especially in connexion with its manifestations in belief, theory and practice in medieval and modern times. Excepting historical and descriptive treatment, scientific analysis of this mass of material has barely begun. Eventually, when its evidence has been sifted and subjected to test, it should provide a valuable corpus of reference in the scientific investigation of manifestations of the 'marvellous'. In the meantime, a comprehensive library of occult literature is indispensable to research, especially in the detection of fraud. Unfortunately, the works which contain contemporary or early records of the facts are often both rare and costly. The University of London Council for Psychical Investigation is fortunate in having at its disposal the library of occult literature formed by Mr. Harry Price, from which a selection of five hundred rarities was on exhibition in December last (see Nature, Dec. 15, 1934, p. 927). In 1929 Mr. Price published a catalogue of the greater part of his library, which contained 10,000 items. To this he has now added a supplement containing an additional 2,500 items acquired since that date (University of London Council for Psychical Investigation, Bull. 1: "Short-Title Catalogue of Works on Psychical Research . . . : From 1472 A.D. to the Present Day", pp. 112. London: 13D Roland Gardens. 2s. 6d.). It is embellished with nine illustrations, title-pages or cuts from rarer books such as Molitor's "De Lamiis et Pythonicis Mulieribus" (c. 1489) or "The Famous History of Friar Bacon" (1660), "very pleasant and delightful to be read" as is recorded on the title-page.

\section{Power Farming in India}

The Imperial Council of Agricultural Research in India has issued, as Scientific Monograph No. 9, a report by C. P. G. Wade, on mechanical eultivation in India, prefaced by an approving foreword and an introduction, written by agricultural officers of the Government. The publication of the report in this form is of special interest, for the work has been inspired, financed and largely carried out by a commercial organisation, the Burmah-Shell Oil Storage and Distributing Co. It is difficult to see how the Government could have given official approval to work of this nature without raising awkward questions of precedent and policy, but for the existence of the Council, the constitution of which, as drawn up by the Linlithgow Commission on Indian Agriculture, was kept flexible and free from 
certain restrictions necessarily observed by Government departments. Much of the work was done co-operatively with the agricultural departments of Provincial Governments. The scheme of work was conceived on broad and public-spirited lines; the Company cannot hope to recover its expenditure by any immediate increase in sales of oil; the most it can expect is to share, in common with other industries, in the increased general prosperity that will accompany any lasting improvement in the agricultural conditions of rural India. Although the greater proportion of Indian cultivators farm under peasant conditions, and cannot directly take up power farming, the question of co-operative use is worthy of attention; in addition, there seems a much larger scope for heavy power machinery on large holdings, for example, planters' estates, and in the reclamation and improvement, under Govern. ment supervision, of large areas. The report deals in detail with an extensive series of experiments on weed eradication by deep cultivation, on contract ploughing and on the analysis of costing data. The concluding chapters are devoted to a discussion of the design and performance of tractors and cultivation implements in relation to Indian conditions, and to the organisation of contract tractor ploughing.

\section{Annual Report of Cheshunt Experimental Station}

THE twentieth Annual Report (1934) of the Experimental and Research Station of the Nursery and Market Garden Industries Development Society, Ltd, has recently been published, from the Station, Turner's Hill, Cheshunt, Herts (pp. 107). The experimental work for 1934 is a continuation of the previous trials of varieties, fertilisers, soil heating, methods of sterilisation and other practices. Mycological investigations include a considerable section on virus diseases, and studies of fungi which attack chrysanthemums, roses, lettuce, carnations and other crops. A new insect parasite of the tomato moth caterpillar has been further described, pests of lettuce and chrysanthemum have received special study, whilst the more common thrips, symphilids and woodlice have also had attention. Insecticide and fungicide investigations have been continued, and the chemists have inquired into the potash content of 'blotchy' tomatoes and the manurial nutrition of chrysanthemums. The effects of light and water content on the growth of tomato plants, with studies on vernalisation, form the main subjects of physiological interest.

\section{Use of Radium in Ireland}

The Irish Radium Committee has issued its report for the year 1934 (Sci. Proc. Roy. Dublin Soc., 21, No. 25, 1935. Separate issue). There was a small increase in the number of batches of radon tubes issued; but a decrease in the total quantity of radon, owing to the continued tendency towards the use of smaller doses, and a considerable increase in the number of cases treated. Little can be gathered from the report of the success or otherwise of the treatment, and an unsatisfactory feature is the fact that some 25 per cent of the patients treated could not be traced after their discharge from hospital.

\section{Prof. P. O. Pedersen}

THe friends of Prof. P. O. Pedersen, principal and professor of electrotechnics of the Royal Technical College, Copenhagen, have published in English some of his papers written in Danish to commemorate his sixtieth birthday, which occurred on June 19, 1934. The subjects discussed are mainly on the development of electrical communication technique, with special reference to contributions by Danes. Excellent work has been done by Gulstad, L. Lorenz, Jensen, C. E. Krarup, Johnsen and Rahbek, Valdemar Poulsen and Prof. Størmer. In a lecture delivered in 1933, Pedersen discusses the possibility of an application of scientific technical methods to other fields of research. The last paper given is on the depreciation of public utilities. In an appendix, a list is given of 97 publications by Pedersen.

\section{New Discoveries of Permian Insect Fossils}

According to Science Service, Washington, D.C., an extensive deposit of fossil insects has been brought to light in a sandstone stratum near the mouth of the Mezer River on the Arctic coast of the U.S.S.R. A preliminary study of these remains has been made by Prof. A. G. Martynov, who finds that all Palæozoic families of insects are represented. Cockroaches are most abundant, but grasshoppers, dragonflies, scorpion flies and other primitive insect groups are also well represented, together with a small number of Coleoptera. An expedition of the Russian Academy of Sciences is at present making collections and studies in the region mentioned. It appears that these insect beds are contemporaneous with the well. known insect-bearing strata of Kansas, which have yielded an abundant fauna.

\section{Japanese Biological Publications}

WE have received vol. 3 , Nos. 1 and 2 of Botany and Zoology, Theoretical and Applied, from Japan. It is a monthly publication, and these two numbers contain 364 and 176 pages respectively. The papers are illustrated and cover every phase of biology, but with the exception of one paper by Prof. Crozier, of Harvard University, they are entirely in Japanese. Only the scientific names and the names of Western authors are given in European characters, except one paper printed in Japanese using the Western alphabet ! It seems a pity that papers, many of which are evidently of considerable general interest, should thus be cut off from Western science. Even Esperanto, which is occasionally being used by the Japanese in their scientific publications, would be preferable as a medium of publication if it is intended to attract the interest of biologists outside Japan.

\section{Scientific Research in Australia}

THE eighth annual report of the Commonwealth of Australia Council for Scientific and Industrial Research shows an increasing range of investigation and a growing number of requests for assistance 